\title{
KAJIAN MEKANISME ANTAGONIS PSEUDOMONAS FLUORESCENS P60 TERHADAP FUSARIUM OXYSPORUM F.SP. LYCOPERSICI PADA TANAMAN TOMAT IN VIVO
}

\author{
Loekas Soesanto $^{1}$, Endang Mugiastuti ${ }^{1}$ \& Ruth Feti Rahayuniati ${ }^{1}$
}

\begin{abstract}
Antagonistic mechanisms study of Pseudomonas fluorescens P60 on Fusarium oxysporum $f$.sp. lycopersici of tomato in vivo. This research was conducted to evaluate the effect of $P$. fluorescens P60 in controlling Fusarium wilt on tomato and its inhibition mechanisms. Randomized Block Design was used with four replicates and each consisted of 12 crops. The treatments tested were combination between supernatant or suspension of P. fluorescens $\mathrm{P} 60$ and application time, i.e., 5 days before planting, in the same time with planting, and 5 days after planting. Variables observed were phenolic compound (tannin, saponin, and glycoside), disease intensity, infection rate, late pathogen and antagonist population density, crop height, stem diameter, fresh and dry weight of roots, and fresh weight of fruit. The result showed that the application of $P$. fluorescens P60 either in supernatant or suspension form, could increase phenolic compound in the crop tissue, decrease the Fusarium wilt intensity on tomato as $66.00-77.88 \%$, suppress infection rate as 73.18-79.09\%, decrease late $F$. oxysporum f.sp. lycopersici density as $35.71 \%$, increase the antagonist as 10 fold, increase crop height as $26.50 \%$, improve root dry weight as $55.69 \%$, and increase fruit weight crop $^{-1}$ as $59.79 \%$. Mechanisms of the antagonist P. fluorescens P60 in order to control the disease in the field were induced resistance, antibiosis, and plant growth promoting rhizobacteria.
\end{abstract}

Key words: Pseudomonas fluorescens P60, Fusarium wilt, tomato, inhibition mechanisms

\section{PENDAHULUAN}

Fusarium oxysporum f.sp. lycopersici merupakan salah satu jamur patogen penting penyebab penyakit layu Fusarium pada tanaman tomat (Semangun, 2000). Jamur dapat menyebabkan kerugian besar, terutama pada varietas tomat rentan dan pada kondisi lingkungan sesuai (Holliday, 1980; Agrios, 2005). Pengendalian yang telah dilakukan, baik dengan fungisida kimia sintetis maupun varietas tahan belum memberikan hasil yang memuaskan. Bahkan penggunaan fungisida sintetis dapat menyebabkan dampak negatif (Untung, 1996; Gamliel et al., 1997). Kultivar tomat tahan terhadap $F$. oxysporum f.sp. lycopersici belum tersedia saat ini. Pengendalian penyakit karena Fusarium dapat dilakukan dengan menambahkan antagonis dan bahan organik ke dalam tanah (Rustati et al., 2004). Pengendalian menggunakan agensia hayati merupakan pilihan yang perlu dikembangkan, sebab relatif murah dan mudah dilakukan, serta bersifat ramah lingkungan.

Pseudomonas kelompok fluorescens merupakan bakteri antagonis yang banyak dimanfaatkan sebagai agensia hayati baik untuk jamur maupun bakteri patogen tanaman. Pseudomonas fluorescens P60 merupakan salah satu strain bakteri antagonis yang telah menunjukkan kemampuannya di dalam mengendalian beberapa patogen tanaman, khususnya patogen tulartanah, baik in vitro, in planta, maupun in vivo. $P$. fluorescens P60 mempunyai sifat "Plant Growth Promoting Rhizobacteria” (PGPR) (Soesanto, 2008), menghasilkan antibiotika 2,4-diasetilfloroglusinol (Phl atau DAPG) (Raaijmakers \& Weller, 1998; Soesanto, 2000) dan siderofor (Alabouvette et al., 1996), mampu mengoloni akar tanaman (Soesanto, 2000), serta mengimbas ketahanan tanaman (Azizah, 2009; Soesanto \& Rahayuniati, 2009).

Antagonis P. fluorescens P60 mampu menghambat pembentukan mikrosklerotium baru Verticilium dahlia pada tanaman uji Arabidopsis thaliana dan terung (Soesanto, 2000; Soesanto, 2001). Selain itu, bakteri ini juga mampu menekan perkecambahan sklerotium jamur Sclerotium rolfsii Sac. in vitro sebesar $92 \%$, mampu menekan intensitas penyakit sebesar $92 \%$, dan menurunkan populasi sklerotium akhir sebesar 86,3\% (Soesanto et al., 2003). Agensia hayati tersebut sudah pernah digunakan untuk mengendalikan penyakit moler pada tanaman bawang

\footnotetext{
${ }^{1}$ Fakultas Pertanian, Universitas Jenderal Soedirman,

J1. Dr. Soeparno Karang Wangkal Purwokerto 53123 Purwokerto. E-mail: lukassus26@ gmail.com
} 
merah (Santoso et al., 2007), S. rolfsii pada kacang tanah (Soesanto, 2004), F. oxysporum f.sp. capsici pada cabai merah (Maqqon et al., 2006), F. oxysporum pada bawang merah (Santoso et al., 2007), F. oxysporum f.sp. gladioli pada tanaman gladiol (Soesanto et al., 2008), dan F. oxysporum f.sp. cubense pada bibit tanaman pisang (Azizah, 2009; Soesanto \& Rahayuniati, 2009).

Bakteri P. fluorescens P60 merupakan salah satu bakteri antagonis berpotensi untuk dikembangkan sebagai agensia pengendali hayati berbagai patogen tular-tanah (Soesanto, 2000), sehingga perlu dilakukan penelitian di lapangan. Penelitian ini bertujuan untuk mengetahui pengaruh aplikasi $P$. fluorescens P60 dalam mengendalikan penyakit layu Fusarium dan macam mekanisme penghambatan P. fluorescens P60 dalam mengendalikan penyakit layu Fusarium pada tomat.

\section{METODE PENELITIAN}

Penelitian in vivo dilaksanakan di lahan percobaan D3 Agribisnis, Fakultas Pertanian, Universitas Jenderal Soedirman, Purwokerto, pada ketinggian 110 $\mathrm{m}$ di atas permukaan laut. Penelitian ini dilaksanakan dari bulan Oktober 2009 sampai Januari 2010.

Perbanyakan dan inokulasi jamur patogen. Perbanyakan isolat patogen dilakukan dengan medium PDA. Biakan murni F. oxysporum pada PDA dipindah secara aseptis ke dalam potato dextrose liquid (PDL) dalam tabung Erlenmeyer, dan digojog (Daiki orbital shaker) dengan kecepatan 150 rpm selama 6 hari pada suhu ruang. Selanjutnya, dihitung kerapatannya sebelum digunakan, dan ditemukan $1,35 \times 10^{7}$ konidium $\mathrm{ml}^{-1}$ larutan. Pemberian F. oxysporum dilakukan bersamaan waktu tanam dengan menyiramkan suspensi atau supernatan antagonis sebanyak $20 \mathrm{ml}$ per lubang sesuai dengan perlakuan.

Penyiapan suspensi dan supernatan antagonis. Suspensi antagonis $P$. fluorescens P60 dibuat dalam medium King's B cair, digojog (Daiki Orbital Shaker) selama 3 hari dengan kecepatan $150 \mathrm{rpm}$ pada suhu ruang. Selanjutnya, antagonis dihitung kerapatannya sebelum digunakan, yaitu sebanyak $1 \times 10^{9}$ konidium $\mathrm{ml}^{-1}$ larutan. Supernatan dibuat dengan cara suspensi antagonis disentrifus (Sigma) pada kecepatan $3000 \mathrm{rpm}$ selama 20 menit. Supernatan yang terbentuk diambil, dipisahkan dari peletnya, dan siap digunakan.
Pembibitan tomat. Benih tomat varietas Ratna dibibitkan dengan menebar benih tomat pada bak plastik yang sudah diberi tanah dan dilembabkan. Setelah berkecambah, bibit dipindah ke medium tanah dalam polibag ukuran $100 \mathrm{~g}$ sampai berumur 3 minggu dan siap digunakan.

Penyiapan lahan tanam. Lahan diolah dengan dicampur pupuk kandang ( 2 ton $\mathrm{ha}^{-1}$ ), dan dibuat bedengan dengan tinggi $30 \mathrm{~cm}$, lebar $80 \mathrm{~cm}$, dan panjang $24 \mathrm{~m}$. Jarak antar-bedengan $60 \mathrm{~cm}$. Lahan dibersihkan dari gulma secara manual.

Perlakuan yang diberikan. Rancangan percobaan yang digunakan adalah Rancangan Acak Kelompok (RAK). Perlakuan yang dicoba yaitu supernatan $P$. fluorescens P60 (P1) dan suspensi P. fluorescens P60 (P2). Perlakuan waktu aplikasi P. fluorescens P60 (W) sebanyak $10 \mathrm{ml}$ per tanaman, yaitu 5 hari sebelum tanam (W0), pada saat tanam (W1), dan 5 hari setelah tanam (W2). Kombinasi perlakukan diulang sebanyak 4 kali dan tiap perlakuan terdiri atas 12 tanaman.

Penanaman dan pemeliharaan. Bibit yang berumur 3 minggu setelah semai dipindah ke lahan, dan bibit ditanam sedalam $5 \mathrm{~cm}$ pada lubang tanam yang sebelumnya telah dibuat, dengan jarak tanaman 50 x 50 $\mathrm{cm}$. Penyiraman dan penyiangan gulma dilakukan sesuai kebutuhan. Pemupukan menggunakan pupuk KCL, TSP, dan ZA sesuai dosis anjuran.

\section{Pengamatan}

Analisis jaringan tanaman. Analisis jaringan tanaman diamati secara kualitatif dengan melakukan uji kandungan senyawa fenol (glikosida, saponin, dan tannin) secara sederhana. Uji dilakukan berdasarkan Chairul (2003) yang dimodifikasi.

Komponen patosistem. Variabel utama yang diamati adalah intensitas penyakit menggunakan rumus berikut (Sudantha et al., 1993) :

$$
\mathrm{IP}=\frac{\sum(\mathrm{n} \times \mathrm{v})}{\mathrm{Z} \times \mathrm{N}} \times 100 \%
$$

Keterangan: IP $=$ Intensitas penyakit $(\%), \mathrm{n}=$ Jumlah daun bergejala dalam setiap kategori, $\mathrm{v}=$ Nilai kategori serangan, $\mathrm{Z}=$ Nilai kategori serangan tertinggi, dan $\mathrm{N}=$ Jumlah daun yang diamati, dengan kategori $0=$ Tidak 
ada gejala, $1=$ Gejala daun menguning $0-20 \%, 2=$ Gejala daun menguning $21-40 \%, 3=$ Gejala daun menguning $41-60 \%, 4=$ Gejala daun menguning $61-80 \%$, dan $5=$ Gejala daun menguning $>80 \%$.

Laju infeksi dihitung berdasarkan rumus van der Plank (1963), yaitu:

$$
r=2,3 / t(\log 1 /(1-X t)-\log 1 /(1-X o))
$$

Keterangan: $\mathrm{r}=$ laju infeksi, $\mathrm{Xo}=$ proporsi penyakit awal, $\mathrm{Xt}=$ proporsi penyakit pada waktu $\mathrm{t}$, dan $\mathrm{t}=$ waktu pengamatan.

Jumlah akhir patogen dan antagonis dihitung dengan mengambil $10 \mathrm{~g}$ tanah rizosfer, dimasukkan ke dalam erlenmeyer berisi $90 \mathrm{ml}$ air kemudian dikocok hingga homogen. Suspensi kemudian diambil 1 tetes ditumbuhkan pada cawan Petri berisi medium PDA padat selama 3 hari untuk jamur patogen, sedangkan untuk antagonis pada medium King's B dan diinkubasi selama 24 jam.

Komponen pertumbuhan dan hasil. Diameter batang diukur pada batang tanaman $5 \mathrm{~cm}$ dari permukaan tanah dengan menggunakan jangka sorong. Tinggi tanaman diukur pada saat pindah tanam dan akhir pengamatan. Bobot basah dan bobot kering akar diperoleh dengan menimbang akar per tanaman, baik sebelum atau sesudah dikeringkan dengan oven pada suhu $35^{\circ} \mathrm{C}$ selama 24 jam; dan bobot buah dilakukan dengan menimbang buah per tanaman pada akhir pengamatan.
Variabel pendukung. Variabel pendukung yang diukur adalah suhu tanah yang diukur dengan termometer tanah, sedangkan kelembaban dan $\mathrm{pH}$ tanah diukur dengan soil tester.

\section{Analisis Data}

Data dianalisis dengan uji $\mathrm{F}$ untuk mengetahui pengaruh perlakuan yang dicoba. Apabila berbeda nyata, dilanjutkan dengan uji DMRT pada tingkat kesalahan $5 \%$.

\section{HASIL DAN PEMBAHASAN}

Analisis Kandungan Senyawa Fenol. Berdasarkan hasil analisis jaringan tanaman tomat secara kualitatif (Chairul, 2003), tampak bahwa pemberian perlakuan bakteri antagonis $P$. fluorescens P60 mampu meningkatkan kandungan senyawa fenol di dalam jaringan tanaman (Tabel 1).

Peningkatan kandungan senyawa fenol (glikosida, saponin, dan tannin) pada tanaman diduga karena pemberian bakteri antagonis. Bakteri antagonis $P$. fluorescens $\mathrm{P} 60$ mampu mengimbas ketahanan tanaman terhadap mikroba patogen. Hal ini selaras dengan penelitian Azizah (2009), bahwa bibit tanaman pisang yang diperlakukan dengan ekstrak bakteri $P$. fluorescens P60 dan P. fluorescens P32 menunjukkan lebih tahan terhadap penyakit layu Fusarium.

Ketahanan kimiawi ditunjukkan dengan terbentuknya senyawa kimia yang mampu mencegah pertumbuhan dan perkembangan patogen. Senyawa yang dimaksud dapat berupa metabolit sekunder,

Tabel 1. Pengaruh perlakuan terhadap kandungan senyawa fenol

\begin{tabular}{cccc}
\hline Perlakuan & Glikosida & Saponin & Tanin \\
\hline K & + & + & + \\
P1W0 & +++ & ++ & +++ \\
P2W0 & +++ & +++ & +++ \\
P1W1 & +++ & +++ & ++ \\
P2W1 & +++ & ++ & ++ \\
P1W2 & +++ & +++ & ++ \\
P2W2 & ++ & +++ & ++ \\
\hline
\end{tabular}

Keterangan: $-=$ tidak ada kandungan fenol, $+=$ sedikit, $++=$ cukup, dan $+++=$ banyak. $\mathrm{K}=$ kontrol, $\mathrm{P} 1=$ supernatan $P$. fluorescens $\mathrm{P} 60, \mathrm{P} 2=$ suspensi $P$. fluorescens $\mathrm{P} 60$, $\mathrm{W} 0=5$ hari sebelum tanam, $\mathrm{W} 1=$ saat tanam, dan $\mathrm{W} 2=5$ hari sesudah tanam. 
diantaranya senyawa alkaloida, fenol, flavonoida, glikosida, fitoaleksin, dan sebagainya (Hammerschmidt \& Dann, 2000; Chairul, 2000 dalam Chairul, 2003; Vallad \& Goodman, 2004). Lebih lanjut dikatakan bahwa senyawa metabolit sekunder tersebut bersifat toksin dan menghambat pertumbuhan patogen, yang dapat mengimbas ketahanan tanaman. Mekanisme ini tidak menghambat pertumbuhan tanaman, tetapi dapat meningkatkan produksi dan ketahanan terhadap stres lingkungan pada beberapa tanaman (Vallad \& Goodman, 2004).

\section{Pengaruh Perlakuan terhadap Komponen}

Patosistem. Hasil analisis intensitas penyakit layu Fusarium, laju infeksi, jumlah akhir patogen, dan jumlah akhir antagonis disajikan pada Tabel 2.

Intensitas penyakit. Hasil analisis data menunjukkan bahwa antara perlakuan dan kontrol berbeda nyata tetapi antar-perlakuan tidak berbeda nyata (Tabel 2). Hal ini menunjukkan bahwa perlakuan dengan supernatan maupun suspensi antagonis dapat menekan intensitas penyakit. Penekanan penyakit dimungkinkan karena $P$. fluorescens P60 mampu hidup di dalam tanah dan mengoloni permukaan akar, sehingga melindungi akar dari serangan $F$. oxysporum f.sp. lycopersici. Hal ini sesuai penelitian Soesanto (2000) dan didukung oleh Widodo (1993), bahwa patogen sukar melakukan penetrasi apabila sistem perakaran terdominasi oleh antagonis.
Intensitas penyakit pada $\mathrm{K}$ (kontrol) sebesar 43,09\%, sedangkan pada P1W1 (supernatan, saat tanam) dan P2W1 (suspensi, 5 hari setelah tanam), yaitu masing-masing sebesar 9,53 dan 14,65\%, atau terjadi penurunan intensitas penyakit sebesar 66,00-77,83\%. Kondisi ini sesuai hasil penelitian Santoso et al. (2007), bahwa $P$. fluorescens P60 mampu menekan intensitas penyakit moler pada tanaman bawang merah, yang disebabkan oleh $F$. oxysporum f.sp. allii, sebesar 41,08\%. Bahkan, P. fluorescens P60 merupakan antagonis yang paling efektif dalam mengendalikan F. oxysporum f.sp. capsici (Maqqon et al., 2006) dan F. oxysporum f.sp. lycopersici (Hastopo et al., 2008).

Menurut Soesanto et al. (2008), perlakuan gabungan antara Trichoderma harzianum, Gliocladium sp., dan P. fluorescens P60 memberikan pengaruh positif dalam menekan penyakit layu Fusarium pada tanaman gladiol hingga 53,98\%. Selain itu, hasil pengujian $P$. fluorescens $\mathrm{P} 60$ in planta terhadap jamur Verticilium dahliae pada tanaman terung menunjukkan bahwa P60 mampu menekan secara nyata infeksi jamur baik yang menyerang batang maupun akar. $P$. fluorescens mampu mengendalikan penyakit layu Verticilium, menghambat pertumbuhan jamur dan pembentukan mikrosklerotiumnya. Gabungan antara P. fluorescens P60 dengan Talaromyces flavus lebih meningkatkan pengendalian $V$. dahliae yang jauh lebih baik dari penerapan secara tunggal (Soesanto \& Termorshuizen, 2001; Soesanto \& Termorshuizen, 2004).

Tabel 2. Pengaruh perlakuan terhadap rerata masa inkubasi, intensitas penyakit layu Fusarium, laju infeksi, jumlah akhir patogen, dan jumlah akhir antagonis

\begin{tabular}{ccccc}
\hline Perlakuan & $\begin{array}{c}\text { Intensitas penyakit } \\
(\%)\end{array}$ & $\begin{array}{c}\text { Laju infeksi } \\
\left(\text { unit hari }^{-1}\right)\end{array}$ & $\begin{array}{c}\text { Jumlah } \\
\text { Akhir patogen } \\
\left(\text { upk g }^{-1}\right)\end{array}$ & $\begin{array}{c}\text { Jumlah } \\
\text { akhir antagonis } \\
\left(\text { upk g }^{-1}\right)\end{array}$ \\
\hline K & $43,09 \mathrm{a}$ & 0,220 & $1,4 \times 10^{4}$ & - \\
P1W0 & $10,38 \mathrm{~b}$ & 0,006 & $8 \times 10^{3}$ & $1,5 \times 10^{10}$ \\
P2W0 & $10,54 \mathrm{~b}$ & $-0,036$ & $9 \times 10^{3}$ & $1,0 \times 10^{10}$ \\
P1W1 & $9,53 \mathrm{~b}$ & $-0,029$ & $1 \times 10^{4}$ & $1,5 \times 10^{10}$ \\
P2W1 & $14,65 \mathrm{~b}$ & 0,046 & $9 \times 10^{3}$ & $1,4 \times 10^{10}$ \\
P1W2 & $11,00 \mathrm{~b}$ & 0,036 & $9 \times 10^{3}$ & $1,2 \times 10^{10}$ \\
P2W2 & $9,69 \mathrm{~b}$ & $-0,059$ & $9 \times 10^{3}$ & $1,7 \times 10^{10}$ \\
\hline
\end{tabular}

Keterangan: Angka yang diikuti huruf yang sama pada kolom yang sama tidak berbeda nyata pada DMRT taraf 5\%. $\mathrm{K}=$ kontrol, $\mathrm{P} 1=$ supernatan $P$. fluorescens $\mathrm{P} 60$, $\mathrm{P} 2=$ suspensi $P$. fluorescens $\mathrm{P} 60, \mathrm{~W} 0=5$ hari sebelum tanam, $\mathrm{W} 1=$ saat tanam, dan $\mathrm{W} 2=5$ hari sesudah tanam. 
Laju infeksi. Laju infeksi penyakit dapat diketahui dari perkembangan intensitas penyakit. Perlakuan bakteri antagonis baik supernatan maupun suspensi berpengaruh positif terhadap laju infeksi yaitu dapat menekan laju infeksi sebesar 73,18-79,09\%. Hal ini diduga karena bakteri P. fluorescens P60 dapat berperan sebagai pesaing patogen, yang sesuai dengan hasil penelitian Soesanto (2000), bahwa strain P. fluorescens P60 menghasilkan antibiotika 2,4-diasetilfloroglusinol (Phl), yang dapat menghambat patogen layu $V$. dahliae pada tanaman kentang dan terung. Jamur patogen seperti $F$. oxysporum tidak menunjukkan kemampuan menghasilkan siderofor jenis yang sama dengan yang dihasilkan bakteri Pseudomonas spp. sehingga jamur patogen mengalami kahat unsur besi, yang menyebabkan pertumbuhan patogen terhambat (Kloepper et al., 1980).

Kepadatan populasi akhir patogen dan antagonis. Dari hasil penghitungan diperoleh kepadatan akhir konidium $F$. oxysporum pada K sebesar $1,4 \times 10^{4}$ upk $\mathrm{g}^{-1}$ tanah, sedangkan pada P1W0 (supernatan, 5 hari sebelum tanam) dan P1W1 (supernatan, saat tanam) masing-masing sebesar $8 \times 10^{3}$ dan $1 \times 10^{4} \mathrm{upk} \mathrm{g}^{-1}$ tanah, atau terjadi penurunan sebesar $28,57-35,71 \%$. Hal ini diduga bakteri $P$. fluorescens $\mathrm{P} 60$ dapat menghambat pertumbuhan patogen, terutama patogen tular-tanah dan mempunyai kemampuan mengoloni akar tanaman. Selain itu, P. fluorescens P60 mempunyai tipe interaksi dengan patogen berupa pesaing hara, penghasil antibiotika, dan siderofor (Soesanto, 2008). Soesanto et al. (2003) menambahkan, perlakuan P. fluorescens P60 konsentrasi $10^{6}$ upk $\mathrm{ml}^{-1}$ mampu menurunkan jumlah sklerotium akhir dan intensitas penyakit busuk pangkal batang karena $S$. rolfsii, berturut-turut 48-86 dan 8299\%. Djatnika et al. (2003) melaporkan bahwa $P$. fluorescens dapat menekan layu Fusarium pada tanaman pisang dengan cara induksi ketahanan, antibiosis, serta memengaruhi tinggi tanaman (Maqqon et al., 2006; Azizah, 2009).

Sementara itu, kepadatan populasi akhir antagonis tertinggi, yaitu sebesar $1,7 \times 10^{10} \mathrm{upk} \mathrm{g}^{-1}$ tanah terdapat pada perlakuan P2W2 (suspensi, 5 hari setelah tanam), yang meningkat dibanding kepadatan awal sebesar $1 \mathrm{x}$ $10^{9}$ upk $\mathrm{ml}^{-1}$ larutan. Tingginya populasi antagonis tersebut diduga karena beberapa sifat atau kemampuan antagonis dalam mendukung kehidupannya. P. fluorescencs P60 mampu mempertahankan diri pada rizosfer, mampu meningkatkan populasinya, menghasilkan senyawa penghambat patogen, dan mampu mengoloni akar tanaman (Soesanto, 2000; Soesanto, 2008).

\section{Pengaruh Perlakuan terhadap Komponen Pertumbuhan dan Hasil Tanaman Tomat. Analisis} statistika terhadap data komponen pertumbuhan tanaman menunjukkan bahwa masing-masing perlakuan menunjukkan perbedaan nyata kecuali pada diameter batang baik terhadap kontrol maupun antar-perlakuan (Tabel 3).

Tabel 3. Pengaruh perlakuan terhadap rerata tinggi tanaman, diameter batang, bobot buah, bobot basah dan bobot kering akar

\begin{tabular}{cccccc}
\hline Perlakuan & $\begin{array}{c}\text { Tinggi tanaman } \\
(\mathrm{cm})\end{array}$ & $\begin{array}{c}\text { Diameter batang } \\
(\mathrm{mm})^{\mathrm{tn}}\end{array}$ & $\begin{array}{c}\text { Bobot buah } \\
\operatorname{tanaman}^{-1}(\mathrm{~g})\end{array}$ & $\begin{array}{c}\text { Bobot basah } \\
\text { akar }(\mathrm{g})\end{array}$ & $\begin{array}{c}\text { Bobot kering } \\
\text { akar }(\mathrm{g})\end{array}$ \\
\hline K & $31,31 \mathrm{c}$ & 7,55 & $20,68 \mathrm{c}$ & $8,18 \mathrm{c}$ & $2,80 \mathrm{~b}$ \\
P1W0 & $35,13 \mathrm{bc}$ & 7,98 & $44,20 \mathrm{ab}$ & $9,66 \mathrm{bc}$ & $4,66 \mathrm{ab}$ \\
P2W0 & $32,28 \mathrm{bc}$ & 7,93 & $21,91 \mathrm{c}$ & $7,38 \mathrm{c}$ & $2,89 \mathrm{~b}$ \\
P1W1 & $42,60 \mathrm{a}$ & 8,32 & $51,44 \mathrm{a}$ & $12,19 \mathrm{~b}$ & $6,32 \mathrm{a}$ \\
P2W1 & $37,80 \mathrm{ab}$ & 8,90 & $32,81 \mathrm{bc}$ & $9,13 \mathrm{bc}$ & $5,35 \mathrm{a}$ \\
P1W2 & $40,80 \mathrm{a}$ & 9,90 & $39,10 \mathrm{ab}$ & $15,25 \mathrm{a}$ & $5,66 \mathrm{a}$ \\
P2W2 & $31,80 \mathrm{c}$ & 7,67 & $38,74 \mathrm{ab}$ & $8,92 \mathrm{c}$ & $3,11 \mathrm{~b}$ \\
\hline
\end{tabular}

Keterangan: Angka yang diikuti huruf yang sama pada kolom yang sama tidak berbeda nyata pada DMRT taraf kesalahan 5\%. $\mathrm{K}=$ kontrol, $\mathrm{P} 1=$ supernatan $P$. fluorescens $\mathrm{P} 60$, $\mathrm{P} 2=$ suspensi $P$. fluorescens $\mathrm{P} 60, \mathrm{~W} 0=5$ hari sebelum tanam, $\mathrm{W} 1=$ pada saat tanam, $\mathrm{W} 2=5$ hari sesudah tanam, dan $\mathrm{tn}=$ tidak nyata. 
Tinggi tanaman dan diameter batang. Hasil sidik ragam menunjukkan bahwa tinggi tanaman tampak berbeda nyata pada masing-masing perlakuan, sedangkan diameter batang tidak berbeda nyata (Tabel 3). Tinggi tanaman pada perlakuan P1W1 (supernatan, saat tanam) dan P1W2 (supernatan, 5 hari setelah tanam), masing-masing sebesar 42,60 dan 40,80 $\mathrm{cm}$ atau terjadi peningkatan sebesar 30,3-36,06\%. Hal tersebut terjadi karena pemberian bakteri $P$. fluorescens P60 mampu menekan patogen sehingga tanaman dapat tumbuh dan berkembang tanpa adanya serangan dari patogen dan mampu meningkatkan pertumbuhan tanaman. Hasil ini sesuai dengan hasil penelitian Maqqon et al. (2006), Santoso et al. (2007), dan Hastopo et al. (2008), yaitu bahwa penerapan antagonis $P$. fluorescens P60 mampu menurunkan tingkat populasi patogen tanaman di dalam tanah dan meningkatkan pertumbuhan tanaman uji.

Selain itu, adanya peningkatan tinggi tanaman karena bakteri $P$. fluorescens P60 mampu menghasilkan senyawa hormon tumbuh sehingga dikenal sebagai "Plant Growth Promoting Rhizobacteria" (PGPR), yang sesuai dengan pendapat Weller (1988), bahwa $P$. fluorescens mampu merangsang pertumbuhan sistem akar dan menghambat jamur dan bakteri yang merugikan. Hal ini terbukti bahwa P. fluorescens P60 mampu menghasilkan auksin paling tinggi bila dibandingkan dengan isolat sejenis lainnya (Dr. Antonius S., LIPI, 2010. Data belum dipublikasi).

Soesanto (2008) menyatakan bahwa bakteri $P$. fluorescens P60 dapat memberikan pengaruh menguntungkan terhadap perkembangan dan pertumbuhan tanaman, yaitu sebagai PGPR. Hasil penelitian Maqqon et al. (2006), Santoso et al. (2007), Soesanto et al. (2008), dan Azizah (2009) membuktikan bahwa bakteri antagonis $P$. fluorescens P60 memberikan pengaruh positif terhadap pertumbuhan tanaman uji, yaitu menyebabkan adanya pertambahan tinggi tanaman.

Hasil sidik ragam terhadap diameter batang pada masing-masing perlakuan tidak memberikan pengaruh nyata (Tabel 3). Namun demikian, pada perlakuan yang mampu meningkatkan tinggi tanaman, yaitu P1W1 (supernatan, saat tanam) dan P1W2 (supernatan, 5 hari setelah tanam), cenderung mempunyai diameter lebih besar jika dibandingkan dengan kontrol (Tabel 3).
Bobot basah dan kering akar. Bobot basah akar tertinggi dijumpai pada perlakuan P1W2 (supernatan, 5 hari setelah tanam) sebesar 15,25 g. Tingginya bobot basah akar tanaman diduga karena adanya mekanisme P. fluorescens P60, di samping melalui penekanan patogen, juga dihubungkan dengan kemampuannya menghasilkan hormon tumbuh yang dapat merangsang pertumbuhan akar tanaman dan berperan sebagai PGPR. Santoso et al. (2007) melaporkan bahwa $P$. fluorescens P60 mampu meningkatkan bobot basah tanaman bawang merah sebesar 51,40\%. Bobot basah akar terendah yaitu pada perlakuan P2W0 (suspensi, 5 hari sebelum tanam) sebesar 7,38 g. Hal ini karena antagonis belum mampu bersaing dengan patogen sehingga perlindungan tanaman tomat terhadap serangan patogen kurang optimum.

Bobot kering akar pada perlakuan P1W1 (supernatan, saat tanam) sebesar 6,32 g, sedang pada $\mathrm{K}$ sebesar 2,80 $\mathrm{g}$ atau terjadi peningkatan sebesar $55,69 \%$. Hal ini diduga selain menghasilkan antibiotika, bakteri P. fluorescens P60 juga berperan sebagai bakteri pemacu pertumbuhan atau PGPR. Hal ini sesuai dengan hasil penelitian Dowling \& O'Gara (1994) dan Khalimi et al. (2008), yang menunjukkan bahwa P. fluorescens secara nyata mampu meningkatkan tinggi tanaman maksimum, jumlah cabang maksimum, jumlah daun maksimum, bobot basah dan kering akar, dan bobot kering biji tanaman kedelai. Gabungan antara $P$. fluorescens P60 dan Trichoderma harzianum dapat meningkatkan bobot kering akar tanaman cabai sebesar 13,4\% (Maqqon et al., 2006).

Bobot buah tomat per tanaman. Bobot buah pada perlakuan P1W1 yaitu sebesar 51,44 g, sedangkan pada $\mathrm{K}$ (kontrol) sebesar 20,68 g, yang selaras dengan bobot akar atau terjadi peningkatan sebesar 59,79\%. Hal ini karena peran bakteri P. fluorescens P60 selain menghasilkan antibiotika, juga mampu sebagai bakteri pemacu pertumbuhan atau PGPR. Mekanisme kerja PGPR diketahui sebagai senyawa yang berfungsi sebagai pemasok zat makanan, antibiosis, sebagai hormon pertumbuhan atau penggabungan dari berbagai cara tersebut, yang dapat sebagai bioaktif dan merangsang perpanjangan akar (Kloepper et al., 1980; Dowling \& O'Gara, 1994). Perpanjangan akar akan mendorong berat basah dan kering akar meningkat, yang 
mengakibatkan pertumbuhan tanaman menjadi lebih baik, dan akhirnya sampai kepada hasil yang meningkat. Hal ini terbukti dari hasil penelitian Soesanto (2004), Maqqon et al. (2006), dan Santoso et al. (2007).

\section{SIMPULAN}

Aplikasi Pseudomonas fluorescens P60, baik dalam bentuk supernatan maupun suspensi, mampu meningkatkan senyawa fenol (tanin, saponin, dan glikosida) di dalam jaringan tanaman, menurunkan intensitas penyakit layu Fusarium, menekan laju infeksi, menurunkan kepadatan akhir patogen, meningkatkan kepadatan antagonis akhir dan meningkatkan tinggi tanaman, bobot kering akar, dan bobot buah per tanaman masing-masing sebesar 66,00-77,88\%, 73,18-79,09\%, $35,71 \%, 10$ kali lipat, 26,50\%, 55,69\%, dan 59,79\%. Pseudomonas fluorescens P60 mempunyai tiga mekanisme dalam mengendalikan penyakit layu Fusarium, yaitu ketahanan terimbas, antibiosis, dan "Plant Growth Promoting Rhizobacteria" (PGPR).

\section{DAFTAR PUSTAKA}

Agrios GN. 2005. Plant Pathology $5^{\text {th }}$ ed. Academic Press, New York.

Alabouvette C, Lemanceau P \& Steinberg C. 1996. Biological control of Fusarium wilts: Opportunities for Developing a Commercial Product. Pp. 192-212. In: Hall R. Principles and Practice of Managing Soilborne Plant Pathogens. APS Press, St. Paul, Minnesota.

Azizah N. 2009. Pengimbasan Ketahanan Bibit Pisang Raja terhadap Penyakit Layu Fusarium dengan Ekstrak Bakteri Antagonis. Skripsi. Fakultas Pertanian Universitas Jenderal Soedirman, Purwokerto (Tidak Dipublikasikan).

Chairul. 2003. Identifikasi secara cepat bahan bioaktif pada tumbuhan di lapangan. Berita Biologi 6(4): 621-628.

Djatnika I, Sunyoto \& Elisa. 2003. Peranan Pseudomonas fluorescens MR96 pada penyakit layu Fusarium tanaman pisang. $J$. Hortikultura 13(3): 212-218.
Dowling DN \& O'Gara F. 1994. Metabolites of Pseudomonas involved in the biocontrol of plant disease. Tibtech. 12: 133-141.

Gamliel A, Grinstein A, Peretz Y, Klein I, Nachmiaz A, Tsror L, Livescu I \& Katan J. 1997. Reduced dosage of methyl bromide for controlling Verticillium wilt of potato in experimental and commercial plots. Plant Dis. 81: 469-474.

Hammerschmidt R \& Dann EK. 2000. Induced Resistance to Disease, Environmentally Safe Approach to Crop Disease Control, Chapter 8. Lewsih Publ., Boca Tayon.

Hastopo K, Soesanto L, \& Mugiastuti E. 2008. Penyehatan tanah secara hayati di tanah tanaman tomat terkontaminasi Fusarium oxysporum f.sp. lycopersici. J. Akta Agrosia 11(2): 180-187.

Holliday P. 1980. Fungus Diseases of Tropical Crops. Cambridge University Press, Cambridge.

Khalimi K \& Wirya GNAS. 2009. Pemanfaatan Plant Growth Promoting Rhizobacteria untuk biostimulants dan bioprotectants. (on-line). http://ejournal.unud.ac.id. Diakses 19 Maret 2010.

Kloepper JW, Leong J, Teintze M \& Schroth MN. 1980. Enhanced Plant Growth by Siderophores Produced by Plant Growth-Promoting Rhizobacteria. Nature 286: 885-886.

Maqqon M, Kustantinah \& Soesanto L. 2006. Penekanan hayati penyakit layu Fusarium pada tanaman cabai merah. Agrosains 8(1): 50-56.

Raaijmakers JM \& Weller DM. 1998. Natural plant protection by 2,4-diacetylphloroglucinolproducing Pseudomonas spp. in take-all decline soils. Molecular Plant-Microbe Interactions 11:144-152.

Rustati R, Soesanto L \& Wachjadi M. 2004. Pengendalian Fusarium oxysporum Schlecht. f.sp. zingiberi Trujillo pada Tanaman Jahe dengan Disinvestasi Tanah secara Hayati. Hal. 
259-267. Dalam: Soesanto L, eds. Prosiding Symposium Nasional I tentang Fusarium, Purwokerto, 26-27 Agustus 2004.

Santoso SE, Soesanto L \& Haryanto TAD. 2007. Penekanan hayati penyakit moler pada bawang merah dengan Trichoderma harzianum, Trichoderma koningii, dan Pseudomonas fluorescens P60. J. Hama dan Penyakit Tumbuhan Tropika 7(1): 53-61.

Semangun H. 2000. Penyakit-penyakit Tanaman Hortikultura di Indonesia. Gadjah Mada University Press, Yogyakarta.

Soesanto L. 2000. Ecological and Biological Control of Verticillium dahliae. Ph.D. Thesis. Wageningen University, Wageningen.

Soesanto L \& Termorshuizen AJ. 2001. Pseudomonas fluorescens P60 sebagai Agensia pengendali Hayati Jamur-Jamur Patogen Tular-tanah. Hal. 183-186. Dalam: Purwantara A, Sitepu D, Mustika I, Mulya K, Sudjono MS, Hidayat SH, Supriadi, Widodo \& Dumalang YE, eds. Prosiding Kongres XVI dan Seminar Nasional PFI, IPB, Bogor 22-24 Agustus 2001.

Soesanto L 2001. Pseudomonas fluorescens P60 sebagai Agensia Hayati Jamur Verticillium dahlia Kleb. J. Penelitian Pertanian Agrin 5(10): 33-40.

Soesanto L, Hidayat R \& Utami DS. 2003. Prospek pemanfaatan Pseudomonas fluorescens P60 untuk pengendalian penyakit busuk batang pada kacang tanah. J. Fitopatologi Indonesia 7(1): $1-6$.

Soesanto L. 2004. Kemampuan Pseudomonas fluorescens P60 sebagai agensia pengendali hayati penyakit busuk batang kacang tanah in vivo. Eugenia 10(1): 8-17.

Soesanto L \& Termorshuizen AJ. 2004. Pengendalian Hayati Verticillium dahliae pada Arabidopsis thaliana dan terung dengan penggabungan Pseudomonas fluorescens dan Talaromyces flavus. Agroland 11(1): 1-10.
Soesanto L, Rokhlani \& Prihatiningsih N. 2008. Penekanan beberapa mikroorganisme antagonis terhadap penyakit layu Fusarium gladiol. Agrivita 30(1): 75-83.

Soesanto L. 2008. Pengantar Pengendalian Hayati Penyakit Tanaman. PT Raja Grafindo Persada, Jakarta.

Soesanto L \& Rahayunati RF. 2009. Pengimbasan ketahanan bibit pisang Ambon Kuning terhadap penyakit layu Fusarium dengan beberapa jamur antagonis. J. Hama dan Penyakit Tumbuhan Tropika 9(2): 130-140.

Sudantha IM, Sridanti NK \& Suheri H. 1993. Penggunaan kompos limbah pertanian untuk pengendalian penyakit layu Fusarium pada tanaman tomat. Hal. 261-268. Risalah Kongres Nasional XII dan Seminar Ilmiah PFI, Yogyakarta.

Untung K. 1996. Pengantar Pengelolaan Hama Terpadu. Gadjah Mada University Press. Yogyakarta.

Vallad GE \& Goodman RM. 2004. Systemic acquired resistance and induced systemic resistance in conventional agriculture. Crop Science Society of America 44: 1920-1934.

van der Plank JE. 1963. Plant Diseases: Epidemics and Control. Academic Press, New York.

Weller DM. 1988. Biological control of soil-borne plant pathogens in the rhizosphere with bacteria. Annu. Rev. Phytopathol. 26: 379-407.

Widodo. 1993. Penggunaan Pseudomonas Kelompok Fluorescens untuk mengendalikan Penyakit Akar Gada pada Caisin (Brassica campestris var. chinensis). Thesis. Institut Pertanian Bogor, Bogor (Tidak dipublikasikan). 